\title{
Tick fauna of wild animals received and attended at the Santarém Zoological Park, western Pará State, Brazil
}

\author{
Kelly Karoline Gomes do Nascimento ${ }^{1}$ Samara Maria Modesto Veríssimo ${ }^{1}$ \\ Vanessa de Almeida Raia ${ }^{1}$ Ruth Cavalcante Silva Guimarães ${ }^{1}$ Gisele Cristine Castro Seade ${ }^{2}$ \\ Adna Cristina Picanço Azevedo ${ }^{1}$ Sidcley Pereira Matos ${ }^{1}$ \\ Jairo Moura de Oliveira ${ }^{3}$ Isis Abel Bezerra ${ }^{1}$ Thiago Fernandes Martins ${ }^{4}$
}

\footnotetext{
${ }^{1}$ Laboratório de Epidemiologia e Geoprocessamento (EpiGeo), Programa de Pós-graduação em Saúde Animal na Amazônia, Universidade Federal do Pará (UFPA), Castanhal, PA, Brasil.

${ }^{2}$ Laboratório de Patologia Animal, Programa de Pós-graduação em Saúde Animal na Amazônia, Universidade Federal do Pará (UFPA), Castanhal, PA, Brasil.

${ }^{3}$ Zoológico das Faculdade Integradas do Tapajós (ZooFIT), Universidade da Amazônia (UNAMA), Santarém, PA, Brasil.

${ }^{4}$ Departamento de Medicina Veterinária Preventiva e Saúde Animal, Faculdade de Medicina Veterinária e Zootecnia, Universidade de São Paulo (USP), Av. Prof. Orlando Marques de Paiva, 87, 05508-000, São Paulo, SP, Brasil. E-mail: thiagodogo@hotmail.com. Corresponding author.
}

ABSTRACT: Ticks are known worldwide for parasitizing a number of wild hosts. However, few studies have been conducted on ticks in zoos in Brazil. The objective of the present study was to collect, identify, and report the parasitic tick fauna found on wild Amazon animals received and attended at the Santarém Zoological Park from September 2004 to September 2013. In all, 56 animals, including 26 mammals and 30 reptiles, were sampled, from which 1172 ticks were collected and identified, comprising 862 adults, 284 nymphs, and 26 larvae. Nymphs of Amblyomma geayi on three-toed sloth (Bradypus tridactylus), adults of Amblyomma longirostre on black dwarf porcupine (Coendou nycthemera), and nymphs of Amblyomma naponense on southern tamandua (Tamandua tetradactyla) were identified for the first time in the country in the present study. Although, the North region is the largest among the five Brazilian regions, this is the first study conducted with ticks and animals attended in a zoo in the Brazilian Amazon.

Key words: Amazon, Amblyomma, Wildlife conservation, Brazil.

Ixodofauna de animais silvestres resgatados e atendidos no Jardim Zoológico de Santarém, oeste do estado do Pará, Brasil

RESUMO: Carrapatos são conhecidos mundialmente por parasitar uma série de hospedeiros silvestres. No entanto, poucos são os estudos realizados com carrapatos em Jardins Zoológicos no Brasil. O presente estudo objetivou coletar, identificar e relatar a fauna parasitária de carrapatos de animais silvestres Amazônicos resgatados e atendidos no Zoológico de Santarém, durante o periodo de setembro de 2004 a setembro de 2013. Ao todo foram amostrados 56 animais incluindo 26 mamíferos e 30 répteis, no qual foram coletados e identificados 1172 carrapatos distribuidos em 862 adultos, 284 ninfas e 26 larvas. Foram identificados de forma inédita no presente estudo ninfas de Amblyomma geayi em preguiça-de-três-dedos (Bradypus tridactylus), adultos de Amblyomma longirostre em ouriço-cacheiro (Coendou nycthemera), além de ninfas de Amblyomma naponense em tamanduá-mirim (Tamandua tetradactyla) no país. Apesar da região Norte ser a maior entre as cinco regiões brasileiras, este é o primeiro trabalho realizado com animais atendidos em Zoológico utilizando os carrapatos como alvo de estudo na Amazônia nacional.

Palavras-chave: Amazônia, Amblyomma, conservação de animais silvestres, Brasil.

\section{INTRODUCTION}

Ticks are known to parasitize a wide range of hosts, including mammals, birds, reptiles, and amphibians. These parasites are significant for veterinary medicine and public health because they are related to the spread of a number of pathogens to animals and humans (NAVA et al., 2017). Zoos can play a role in bio surveillance, serving as an advanced guard for detecting exotic arthropods and vectorborne diseases (ADLER et al., 2011).

Although, Brazil is a country with vast territory and has approximately 120 zoos WEMMER et al. (2006), few studies have been 
conducted on ticks in zoos. These studies are mostly concentrated in the Southeast region of the national territory, with the Sorocaba Zoo being the pioneer (TEIXEIRA et al., 2003, 2008, 2017; MARTINS et al., 2015b; GONZALEZ et al., 2017). Other studies have been conducted in the South and Northeast regions of the Brazilian territory (BRUM \& RICKES, 2003; DANTAS-TORRES et al., 2010a, 2010b; PEREIRA et al., 2012).

The Tapajós Integrated Faculties Zoo, University of Amazon (Zoo FIT/UNAMA), located in the municipality of Santarém, Lower Amazon mesoregion of the state of Pará, was created in 1993 to receive, treat, and adequately shelter many species of wild animals of the Amazon fauna, which, due to anthropogenic actions (mainly deforestation), arrive at the Integrated Faculties of the Tapajós following seizures carried out by government agencies (ZOOFIT, 2017).

The zoo is located on an area of 147 hectares provided by the Ministry of Defense (Brazilian Army $/ 8^{\text {th }}$ Battalion of Engineering and Construction) and contains approximately 54 species of wild animals, kept in enclosures according to the specifications of current legislation. Zoo FIT/UNAMA, in addition to being useful to scientific research, particularly regarding knowledge on the fauna of the Amazon, contributes to regional development through animal releases and environmental education, thus stimulating the local preservation of endangered wild animal species (ZOOFIT, 2017).

Because knowledge on the tick fauna that parasitize wild animals in zoos is relevant (ADLER et al., 2011), the objective of the present study was to collect, identify, and report the parasitic tick fauna of wild Amazon mammals and reptiles received and attended at the Santarém Zoological Park.

\section{MATERIALS AND METHODS}

Ticks of wild animals at Zoo FIT/ UNAMA were collected from September 2004 to September 2013. All the animals were rescued and taken to the Zoo by the local population and by the Fire Brigade. A total of 56 animals originating from different locations in the municipality of Santarém (2²6’34'S, 5442’28' W) were sampled, including 26 mammal specimens and 30 reptile specimens of different age groups and sexes. The animals analyzed were 18 three-toed sloths (Bradypus tridactylus), one two-toed sloth (Choloepus didactylus), one black dwarf porcupine (Coendou nycthemera), six southern tamanduas (Tamandua tetradactyla), 25 red-tailed boa (Boa constrictor), one green anaconda (Eunectes murinus), two green iguanas (Iguana iguana), and two Amazon false fer-de-lances (Xenodon severus).

During the clinical evaluation and routine management, all animals received from nature were inspected for the presence of ticks as soon as they arrive at the zoo, and the ectoparasites were removed and stored in $70 \%$ ethanol for taxonomic identification according to BARROS-BATTESTI et al. (2006) and MARTINS et al. (2010, 2013), using a Zeiss Stemi Sv11 stereoscope. Collected ticks were deposited in the tick collection "Coleção Nacional de Carrapatos Danilo Gonçalves Saraiva" (CNC) of the University of São Paulo under accession numbers CNC-3535-3542.

\section{RESULTS AND DISCUSSION}

In total, 1,172 ticks were collected and identified, comprising 862 adults, 284 nymphs, and 26 larvae. The identification of ixodid ticks and their respective hosts is shown in table 1.

The tick Amblyomma dissimile is often reported parasitizing reptiles (GUGLIELMONE \& NAVA, 2010). In the present study, $A$. dissimile was found on B. constrictor, E. murinus, I. iguana, and $X$. severus, thus corroborating the findings of GUGLIELMONE \& NAVA (2010), who also reported these four species of reptiles as hosts of $A$. dissimile.

Ticks species Amblyomma geayi and Amblyomma varium are usually recorded parasitizing sloths (MARQUES et al., 2002; LABRUNA et al., 2009; SOUZA et al., 2016). In the present study, adults of $A$. geayi and adults and nymphs of $A$. varium were identified on $B$. tridactylus, corroborating the studies of SERRAFREIRE et al. (1993) and MARQUES et al. (2002), who also identified adults of these same species of ticks in this same host in the North region of Brazil. Additionally, in the present study, ten nymphs of $A$. geayi were identified from $B$. tridactylus for the first time; nymphs of this species of tick had only been previously reported in the Brazilian Amazon region in Bradypus variegatus by MARTINS et al. (2013) in the municipality of Belém, state of Pará.

The tick Amblyomma longirostre is commonly reported parasitizing porcupines during the adult stage (NAVA et al., 2010). In the present study, two adults of $A$. longirostre were reported on $C$. nycthemera. However, NAVA et al. (2010) recorded $A$. longirostre from three species of the genus Coendou: Coendou bicolor, Coendou prehensilis, and Coendou rothschildi. Therefore, the present study is the first report of a new host for this tick species in Brazil. 
Table 1 - Ticks identified on wild animals received and attended at theTapajós Integrated Faculties Zoo, University of Amazon, municipality of Santarém, western Pará State, Brazil, from September 2004 to September 2013.

\begin{tabular}{|c|c|c|c|c|c|c|c|}
\hline \multirow[t]{2}{*}{ Species of tick } & \multicolumn{3}{|c|}{--------------Stages-------------- } & \multirow[t]{2}{*}{ Host (n) } & \multicolumn{3}{|c|}{----Mean infestation intensity $\left({ }^{*}\right)----$} \\
\hline & A & $\mathrm{N}$ & $\mathrm{L}$ & & A & $\mathrm{N}$ & $\mathrm{L}$ \\
\hline & & & & Reptiles & & & \\
\hline Amblyomma sp. & - & - & 2 & B. constrictor (1) & 0.0 & 0.0 & 2.0 \\
\hline A. dissimile & 514 & 239 & - & B. constrictor $(24)$ & 21.4 & 9.9 & 0.0 \\
\hline A. dissimile & 21 & 3 & - & E. murinus (1) & 21.0 & 3.0 & 0.0 \\
\hline A. dissimile & 4 & - & - & I. iguana (2) & 2.0 & 0.0 & 0.0 \\
\hline \multirow[t]{2}{*}{ A. dissimile } & 8 & - & - & $X$. severus (2) & 4.0 & 0.0 & 0.0 \\
\hline & & & & Mammals & & & \\
\hline Amblyomma sp. & - & - & 24 & B. tridactylus (1) & 0.0 & 0.0 & 24.0 \\
\hline A. varium & 21 & 5 & - & B. tridactylus (2) & 10.5 & 2.5 & 0.0 \\
\hline A. geayi & 197 & 10 & - & B. tridactylus (15) & 13.1 & 0.6 & 0.0 \\
\hline A. geayi & 1 & - & - & C. didactylus (1) & 1.0 & 0.0 & 0.0 \\
\hline A. longirostre & 2 & - & - & C. nycthemera (1) & 2.0 & 0.0 & 0.0 \\
\hline A. goeldii & 19 & - & - & T. tetradactyla (1) & 19.0 & 0.0 & 0.0 \\
\hline A. humerale & - & 23 & - & T. tetradactyla $(1)$ & 0.0 & 23.0 & 0.0 \\
\hline A. naponense & - & 4 & - & T. tetradactyla (1) & 0.0 & 4.0 & 0.0 \\
\hline A. nodosum & 75 & - & - & T. tetradactyla (3) & 25.0 & 0.0 & 0.0 \\
\hline
\end{tabular}

(The number of individuals analyzed is in parentheses).

$\left(^{*}\right)$ Mean infestation intensity (total number of ticks / number of infested animals).

A: adult; N: nymph; L: larva.

The ticks Amblyomma goeldii and Amblyomma nodosum have also been described as parasitizing southern tamanduas during the adult stage (MARTINS et al., 2014, 2015a; SOARES et al., 2015). In the present study, adults of $A$. goeldii and A. nodosum were identified on T. tetradactyla, corroborating MARTINS et al. $(2014,2015 \mathrm{a})$ and SOARES et al. (2015), who also identified southern tamanduas as hosts for these two species of ixodids in the North region of the country.

In the present study, 23 nymphs of the species Amblyomma humerale were identified on $T$. tetradactyla. In addition, four nymphs of Amblyomma naponense were identified on this same host species. Nymphal stage of $A$. humerale was recently recorded in southern tamanduas (SOARES et al., 2015; WITTER et al., 2016). In contrast, the identification of $A$. naponense nymphs on T. tetradactyla is reported for the first time in Brazil, thus contributing further to the knowledge on the biology and ecology of this understudied tick species.

According to literature, infections with Rickettsia species have been previously reported in some tick species collected in the present study. Specimens of the tick $A$. dissimile have been reported to be infected with Rickettsia sp. strain colombianensi (MIRANDA et al., 2012); A. geayi, with Rickettsia amblyommatis (OGRZEWALSKA et al., 2010); A. varium, with $R$. amblyommatis and Rickettsia bellii (OGRZEWALSKA et al., 2012; LUGARINI et al., 2015); $A$. longirostre, with $R$. amblyommatis (LABRUNA et al., 2004); the tick $A$. nodosum, with Rickettsia parkeri-like agent and $R$. bellii (OGRZEWALSKA et al., 2009); and finally, $A$. humerale, with $R$. bellii (LABRUNA et al., 2004). Of the eight species of ticks reported in the present study, there are already reports of infection with Rickettsia species in six; therefore, future epidemiological studies should be conducted in this still little-explored biome, once $R$. parkeri is pathogenic for humans (OGRZEWALSKA et al., 2009).

\section{CONCLUSION}

Although, the North region of the country is the largest among the five Brazilian regions and is where the Amazon biome predominates, this is the first study conducted in a zoo using ticks as a target of study in the Brazilian Amazon. Thus, it is necessary to conduct further studies to increase the knowledge of the invertebrates that parasitize wild vertebrates, particularly the Amazon tick fauna. 


\section{ACKNOWLEDGMENTS}

The authors thank Dr. Alberto A. Guglielmone (INTA, Rafaela, Argentina) for providing data from his extensive archive of Neotropical ticks, Dr. Marcelo B. Labruna for the deposit of it in the tick collection "Coleção Nacional de Carrapatos Danilo Gonçalves Saraiva" (CNC) of the Universidade de São Paulo, and the PIBIC/UFPA, PNPD/Capes and Procad/Capes programs for the scholarships. This study received funding from the Fundação de Amparo à Pesquisa do Estado de São Paulo (FAPESP, Project 2014/14464-1) and the Coordenação de Aperfeiçoamento de Pessoal de Nível Superior (CAPES) (PROCAD, $\mathrm{n}^{\circ} 88881.068412 / 2014$ 01). We thank the Instituto Chico Mendes de Conservação da Biodiversidade (ICMBio) for permission number (11459-1).

\section{REFERENCES}

ADLER, P.H. et al. Arthropods of medicoveterinary importance in zoos. Annual Review of Entomology, v.56, p.123-142, 2011. Available from: <http://www.annualreviews.org/doi/pdf/10.1146/ annurev-ento-120709-144741>. Accessed: May 26, 2017.

BARROS-BATTESTI, D.M. et al. Carrapatos de importância médico-veterinária da região neotropical: um guia ilustrado para identificação de espécies. São Paulo: Vox/ICTTD-3/Butantan, 2006. 223p.

BRUM, J.G.W.; RICKES, E.M. Amblyomma dissimile Koch, 1844 (Acari: Ixodidae) em serpente sucuri (Eunectes murinus) (Reptilia: Boidae) no parque zoológico do Rio Grande do Sul. Arquivos do Instituto Biológico, v.70, n.2, p.215-216, 2003. Available from: $<$ http://www.biologico.sp.gov.br/docs/arq/V70_2/brum3.pdf $>$. Accessed: Nov. 12, 2016.

DANTAS-TORRES, F. et al. Ticks on captive and free-living wild animals in northeastern Brazil. Experimental and Applied Acarology, v.50, p.181-189, 2010a. Available from: <https://www. ncbi.nlm.nih.gov/pubmed/19693679,doi:10.1007/s10493-0099296-5>. Accessed: Dec. 22, 2016.

DANTAS-TORRES, F. et al. Ticks infesting wildlife species in northeastern Brazil with new host and locality records. Journal of Medical Entomology, v.47, n.6, p.12431246, 2010b. Available from: $<$ http://www.bioone.org/doi/full/10.1603/ME10156>. Accessed: Nov. $26,2016$.

GONZALEZ, I.H.L. et al. Ticks infesting captive and free-roaming wild animal species at the São Paulo Zoo, São Paulo, Brazil. Revista Brasileira de Parasitologia Veterinária, 2017. In Press.

GUGLIELMONE, A.A.; NAVA, S. Hosts of Amblyomma dissimile Koch, 1844 and Amblyomma rotundatum Koch, 1844 (Acari: Ixodidae). Zootaxa, v.2541, p.27-49, 2010. Available from: $<$ http://www.mapress. com/zootaxa/2010/f/z02541p049f.pdf>. Accessed: Dec. 05, 2016.

LABRUNA, M.B. et al. Rickettsia bellii and Rickettsia amblyommii in Amblyomma ticks from the State of Rondônia, Western Amazon, Brazil. Journal of Medical Entomology, v.41, n.6, p.1073-1081, 2004. Available from: <http://www.bioone.org/ doi/abs/10.1603/0022-2585-41.6.1073>. Accessed: May 26, 2017.

LABRUNA, M.B. et al. Redescription of the female, description of the male, and several new records of Amblyomma parkeri (Acari: Ixodidae), a South American tick species. Experimental and Applied Acarology, v.49, p.243-260, 2009. Available from:
$<$ https://www.ncbi.nlm.nih.gov/pubmed/19241123,doi: 10.1007/ s10493-009-9257-z>. Accessed: Nov. 12, 2016.

LUGARINI, C. et al. Rickettsial agents in avian ixodid ticks in northeast Brazil. Ticks and Tick-borne Diseases, v.6, n.3, p.364375, 2015. Available from: < http://www.sciencedirect.com/science/ article/pii/S1877959X15000370>. Accessed: May 26, 2017.

MARQUES, S. et al. Brazilian distribution of Amblyomma varium Koch, 1844 (Acari: Ixodidae), a common parasite of sloths (Mammalia: Xenarthra). Memórias do Instituto Oswaldo Cruz, v.97, n.8, p.1141-1146, 2002. Available from: <http://dx.doi. org/10.1590/S0074-02762002000800014>. Accessed: Oct. 20, 2016.

MARTINS, T.F. et al. Nymphs of the genus Amblyomma (Acari: Ixodidae) of Brazil: descriptions, redescriptions, and identification key. Ticks and Tick-borne Diseases, v.1, n.2, p.75-99, 2010. Available from: <http://dx.doi.org/10.1016/j.ttbdis.2010.03.002>. Accessed: Dec. 12, 2016.

MARTINS, T.F. et al. Morphological description of the nymphal stage of Amblyomma geayi and new nymphal records of Amblyomma parkeri. Ticks and Tick-borne Diseases, v.4, n.3, p.181-184, 2013. Available from: <http://dx.doi.org/10.1016/j. ttbdis.2012.11.015>. Accessed: Nov. 15, 2016.

MARTINS, T.F. et al. New tick records from the state of Rondônia, western Amazon, Brazil. Experimental and Applied Acarology, v.62, n.1, p.121-128, 2014. Available from: <https://www.ncbi. nlm.nih.gov/pubmed/23975565, doi:10.1007/s10493-013-97244>. Accessed: Dec. 23, 2016.

MARTINS, T.F. et al. New records of Amblyomma goeldii (Acari: Ixodidae) and description of the nymphal stage. Zootaxa, v.3949, n.3, p.439-444, 2015a. Available from: $<$ http://biotaxa.org/Zootaxa/ article/view/zootaxa,dx.doi.org/10.11646/zootaxa.3949.3.9>. Accessed: Nov. 15, 2016.

MARTINS, T.F. et al. Ocorrência de carrapatos em animais silvestres recebidos e atendidos pelo Parque Zoológico Municipal Quinzinho de Barros, Sorocaba, São Paulo, Brasil. Brazilian Journal of Veterinary Research and Animal Science, v.52, n.4, p.319-324, 2015b. Available from: <http://dx.doi.org/10.11606/ issn.1678-4456.v52i4p319-324>. Accessed: Nov. 10, 2016.

MIRANDA, J. et al. Rickettsia sp. strain colombianensi (Rickettsiales: Rickettsiaceae): a new proposed Rickettsia detected in Amblyomma dissimile (Acari: Ixodidae) from iguanas and free-living larvae ticks from vegetation. Journal of Medical Entomology, v.49, n.4, p.960-965, 2012. Available from: <http://www.bioone.org/doi/ abs/10.1603/ME11195>. Accessed: May 26, 2017.

NAVA, S. et al. First record of Amblyomma longirostre (Koch 1844) (Acari: Ixodidae) from Peru, with a review of this tick's host relationships. Systematic and Applied Acarology, v.15, n.1, p.2130, 2010. Available from: <http://dx.doi.org/10.11158/saa.15.1.2>. Accessed: Dec 18, 2016.

NAVA, S. et al. Ticks of the Southern Cone of America: diagnosis, distribution and hosts with taxonomy, ecology and sanitary importance. London: Elsevier, 2017. 372p.

OGRZEWALSKA, M. etal. Rickettsial infection in Amblyomma nodosum ticks (Acari: Ixodidae) from Brazil. Annals of Tropical Medicine and Parasitology, v.103, n.5, p.413-425, 2009. Available from: <http://dx.doi. org/10.1179/136485909X451744>. Accessed: May 26, 2017. 
OGRZEWALSKA, M. et al. Ticks (Acari: Ixodidae) infesting wild birds in the eastern Amazon, northern Brazil, with notes on rickettsial infection in ticks. Parasitology Research, v.106, n.4, p.809-816, 2010. Available from: <http://dx.doi.org/10.1007/ s00436-010-1733-1>. Accessed: May 26, 2017.

OGRZEWALSKA, M. et al. Rickettsia bellii in ticks Amblyomma varium Koch, 1844, from birds in Peru. Ticks and Tick-borne Diseases, v.3, n.4, p.254-256, 2012. Available from: <http://www. sciencedirect.com/science/article/pii/S1877959X12000428>. Accessed: May. 26, 2017.

PEREIRA, J.S. et al. Infestação por carrapatos em Boa constrictor constrictor (Linnaeus, 1758) de cativeiro, em Mossoró, Rio Grande do Norte. Revista Brasileira de Zoociências, v.14, n.1,2,3, p.41-44, 2012. Available from: <https://zoociencias.ufjf.emnuvens.com.br/ zoociencias/article/download/1103/1995>. Accessed: Nov. 30, 2016.

SERRA-FREIRE, N.M. et al. Amblyomma geayi Neumann, 1899 parasito de Bradypus tridactylus no Estado de Tocantins, Brasil. Revista Brasileira de Parasitologia Veterinária, v.2, n.1, p.5, 1993.

SOARES, H.S.et al. Ticks and rickettsial infection in the wildlife of two regions of the Brazilian Amazon. Experimental and Applied Acarology, v.65, n.1, p.125-140, 2015. Available from: $<$ https:/www.ncbi.nlm.nih.gov/pubmed/25273064,doi:10.1007/ s10493-014-9851-6>. Accessed: Nov. 01, 2016.

SOUZA, S.F.et al. Primeiro registro de Amblyomma geayi (Acari: Ixodidae) em preguiça (Bradypus variegatus) no estado do Acre, Amazônia Ocidental: relato de caso. Arquivo Brasileiro de
Medicina Veterinária e Zootecnia, v.68, n.4, p.953-957, 2016. Available from: <http://www.scielo.br/pdf/abmvz/v68n4/01020935-abmvz-68-04-00953.pdf>. Accessed: May 26, 2017.

TEIXEIRA, R.H.F. et al. Ixodofauna de répteis cativos no Zoológico de Sorocaba, São Paulo, Brasil. Entomologia y Vectores, v.10, n.3, p.319-329, 2003.

TEIXEIRA, R.H.F. et al. Carrapatos em aves selvagens no Zoológico de Sorocaba - São Paulo, Brasil. Arquivo Brasileiro de Medicina Veterinária e Zootecnia, v.60, n.5, p.12771280, 2008. Available from: <http://dx.doi.org/10.1590/S010209352008000500037>. Accessed: Dec. 21, 2016.

TEIXEIRA, R.H.F. et al. Ixodídeos coletados parasitando animais selvagens no Zoológico de Sorocaba, Estado de São Paulo, Brasil. Revista de Educação Continuada em Medicina Veterinária e Zootecnia do CRMV-SP, v.15, n.1, p.8-14, 2017. Available from: $<$ http://www.crmvsp.gov.br/arquivo_midia/revista_educacao_ continuada_vol_15_No_1_2017.pdf>.Accessed: May 26, 2017.

WEMMER, C. et al. Manual do técnico de zoológico. Balneário Camboriú: Sociedade de Zoológicos do Brasil, 2006. 180p.

WITTER, R. et al. Rickettsial infection in ticks (Acari: Ixodidae) of wild animals in midwestern Brazil. Ticks and Tick-borne Diseases, v.7, n.3, p.415-423, 2016. Available from: <http://dx.doi. org/10.1016/j.ttbdis.2015.12.019>. Accessed: Dec. 18, 2016.

ZOOFIT. Available from: <http://zoofit.fit.br/>. Accessed: Jan. 20, 2017. Online. 